\title{
Performance and Risk Comparison Analysis of Optimal Portfolio of Shares LQ-45 Using Single Index Model and Capital Asset Pricing Model August 2017 - January 2020 Period
}

\author{
Dikri Cakrawala Uno and Andam Dewi Syarif
}

\section{ABSTRACT}

The purpose of this research is to determine the differences between performance and risks optimal portfolio of Single Index Model (SIM) and Capital Asset Pricing Model (CAPM) in the period August 2017 - January 2020. This research is a descriptive study with a quantitative approach. The data collection technique used is documentation study. Based on the results of the calculation, it is found that there is a difference return of the SIM portfolio to CAPM, there is no difference risk of the SIM portfolio to CAPM, there is a difference performance of the SIM portfolio that evaluated using the Sharpe, Treynor and Jansen methods and there is no difference performance of the CAPM portfolio that evaluated using the Sharpe, Treynor and Jansen method.

Keywords: LQ45, Optimal Portfolio, Single Index Model, Capital Asset Pricing Model, Optimal Portfolio Performance.

Published Online: January 28, 2021

ISSN: 2507-1076

DOI: $10.24018 /$ ejbmr.2021.6.1.700

Dikri Cakrawala Uno *

Mercu Buana University, Jakarta, Indonesia.

(e-mail: dcuno1993@ gmail.com)

Andam Dewi Syarif

Mercu Buana University, Jakarta, Indonesia.

(e-mail: andam.dewi@mercubuana.ac.id)

*Corresponding Author

\section{INTRODUCTION}

The LQ 45 index is one of the indices that investors refer to on the stock exchange. The stock index consists of companies with high liquidity, making it easier for investors to select several stocks but they represent the overall stock market performance. To analyze the performance of the LQ 45 index, the index value for each period becomes a reference for investing.

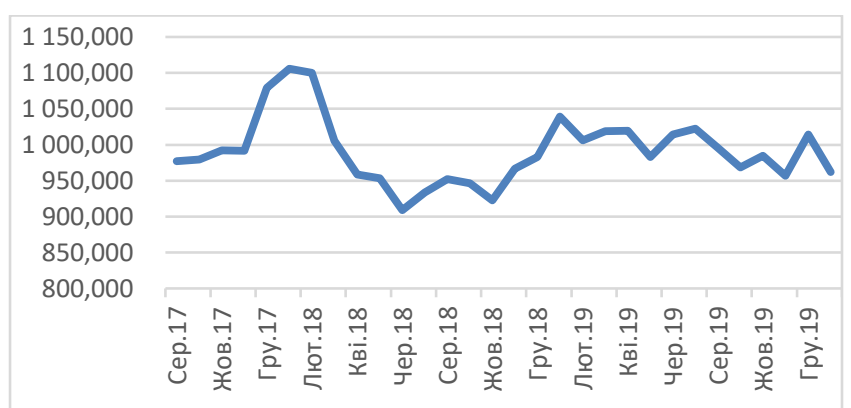

Fig. 1. LQ-45 Index Value for the period August 2017 - January 2020.

The movement of the LQ 45 index fluctuates, where the lowest value occurred in January 2017 and the highest value occurred in January 2018. The psychology of an investor in investing is high risk, high return [1].

Currently, there are many methods that are often used by investors to form optimal portfolios. Of course, each method used as a portfolio formation tool will provide different formation results. The author chose to compare the Single Index Model (SIM) and Capital Asset Pricing Model
(CAPM) methods because the CAPM method was formed and considered to improve the SIM method.

According to several literature studies there are several methods commonly used internationally in assessing portfolio performance, namely by using the Sharpe Ratio [2], Treynor Ratio and Jensen Ratio [3]. The three methods use variables such as rate of return, beta, alpha, benchmarks, systematic risk, unsystematic risk and standard deviation of each portfolio, so that in this study the authors are interested in comparing the performance results of the optimal portfolio formed. So, the question arises that which of the two methods has the most appropriate performance and makes it easy for investors. This study only uses SIM and CAPM with the LQ 45 stock index with the research period only during the period August 2017 - January 2020. This does not yet provide different stock investment options.

\section{LITERATURE REVIEW}

An efficient portfolio is not necessarily an optimal portfolio. An efficient portfolio has only one good factor, namely the expected return factor or the risk factor alone, not the best of both. The optimal portfolio is a portfolio with the best combination of risk and expectation returns [4].

One of the optimal portfolio determination procedures is the single index method. The single index method describes the relationship between the returns of each individual security and the market returns. SIM model comparing ERB with Ci [5].

With the concept of calculation based on the order of shares through the ERB sequence [6]. The ranking aims to determine the advantages of stock returns on risk-free 
returns per unit risk. Stocks that have an excess return to beta (ERB) equal to or greater than the cut-off-point $\left(\mathrm{C}^{*}\right)$ are candidates for optimal portfolio formation.

In calculating the level of profit on their portfolio, investors need an analytical tool. The establishment of general equilibrium models allow investors to determine relevant risk measures. CAPM is a balance model.

CAPM is a model that emphasizes the expected return on a security which is a linear function towards the positive of a security's sensitivity to changes in its market portfolio returns [7]. CAPM is commonly used to compare risk and expected return on investment [8].

All investors have the same level of expectation of the expected returns (variance of returns, covariance) in portfolio decision making. All investors use the same oneperiod time horizon. There are no transaction fees. There is no personal income tax. There is no inflation. Securities price movements are influenced by many investors not only by an investor. The capital market is in a state of equilibrium (equilibrium) [8].

CAPM systematic risk is no longer measured by the standard deviation of the level of profit but is measured by beta $(\beta)$. Beta in the CAPM analysis model shows the sensitivity of stock returns to market movements, in other words, each stock has a relationship with the market (market) or the portfolio it forms [8].

The CAPM method states that the greater the beta $\mathrm{i}(\beta \mathrm{i})$, the greater the return obtained. Stocks that have $(\beta i>1)$ are stocks with the highest risk and stocks that have $(\beta \mathrm{i}<1)$ are stocks with the lowest risk.

The development of the concept of portfolio performance measurement occurred in the late 60's which was pioneered by Wiliam Sharpe, Trenor, and Michael Jensen. This concept is based on Capital Market theory. These three measures are known as composite (risk-adjusted).

One of the methods used to compare portfolio performance is using the concept of the Capital Market Line (CML) or better known as the Reward to Variability Ratio (RVAR). Where Sharpe states that the portfolio performance series is calculated as the net result of the portfolio with a risk-free interest rate per unit risk, given the symbol Sp [2].

If the portfolio is highly diversified, the total risk is almost the same as the systematic risk because unsystematic risk is close to zero. It can also be called if the portfolio is the same as the market portfolio, the total risk is the same as the systematic risk or market risk or it can be called beta.

Treynor as an index used to measure portfolio performance, Treynor assumes that a highly diversified portfolio is known as the Reward to Valatility Ratio (RVOR). Therefore, the Treynor index states that the portfolio performance series is calculated as the net result of the portfolio with a risk-free interest rate per unit of market risk for the portfolio with the symbol Tp [9].

As a measure of portfolio performance, Jensen pays close attention to CAPM in measuring portfolio performance which is often referred to as the Jesen ALPHA (differential return measure). Jensen ALPHA is an absolute measure that estimates a constant rate of return during the investment period where Jesen ALPHA gets a return above (below) from the buy-hold strategy with the same systematic risk [3].

The analysis stage begins by identifying stocks that are consistent and do not split stock on LQ-45 for the period August 2017 to January 2020, after obtaining consistent stocks in that period, then using monthly close price data on LQ-45 shares during past three years, calculations have been made to form a stock portfolio of SIM and CAPM models. After these two portfolios are formed, of course both have different returns and levels of risk, so it is necessary to test the performance of the portfolio to find out the extent to which the portfolios formed can provide results for investors, testing the performance of the portfolios will be carried out with the Sharpe, Treynor model, and Jensen.

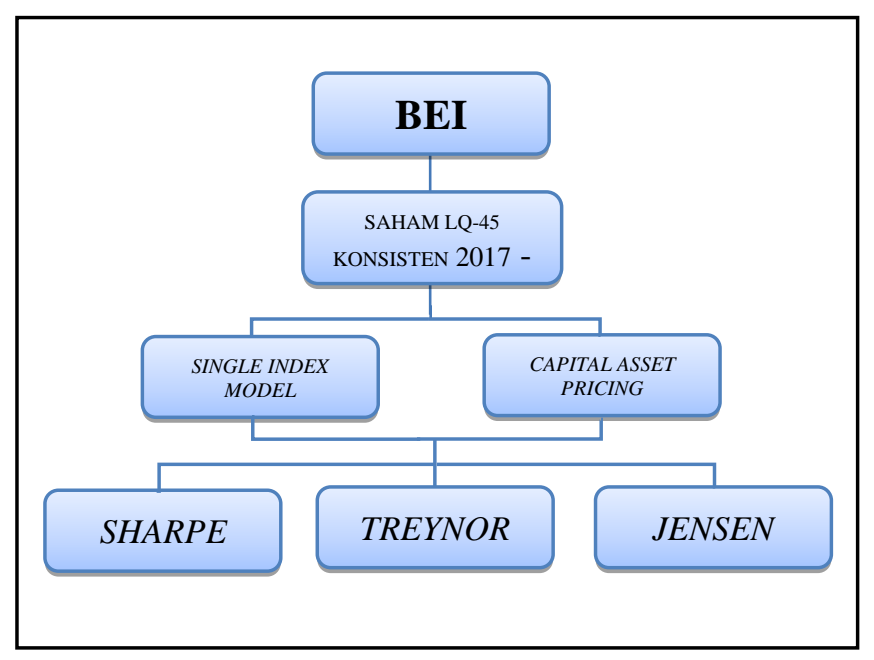

Fig. 2. Framework.

\section{RESEARCH METHODS}

The population in this study uses a population in the form of stocks belonging to the LQ-45 stocks which are listed on the Indonesia Stock Exchange (BEI). The sampling technique was carried out by purposive sampling method so that 33 companies were obtained.

The Single Index Model (SIM) method uses the calculation of realized stock returns, expected stock returns, market realized returns, expected market returns, stock return variants, market return variants, stock standard deviation, and market standard deviation for each stock, and determines the proportion stocks to form an optimal portfolio and Capital Asset Pricing Model (CAPM) with the calculation of return and standard deviation of stocks, return and market risk, determine Beta and unsystematic risk for each stock, and determine the proportion of shares to form an optimal portfolio.

To find out whether there are significant differences, it is necessary to test the hypothesis to compare the return, risk and performance of the portfolio formed using the Single Index Model and the return, risk and performance formed using the Captial Asset Pricing Model. Hypothesis testing is done by means of Two-Mean Difference Test for Related Samples / related samples (Paired Samples Different Test ttest). 


\section{RESUlT}

The following is the result of data processing for the LQ45 Index for the period August 2017 - January 2020.

TABLE I: RESUlTS OF LQ-45 INDEX STOCK DATA PROCESSING PERIOD

\begin{tabular}{ccccccc}
\multicolumn{7}{c}{ AUGUST $2017-$ JANUARY 2020 } \\
\hline No & Kode & E $(\mathrm{Ri})$ & $(\sigma \mathrm{i})$ & $(\sigma \mathrm{i})$ & $\beta$ & $\alpha$ \\
\hline 1 & ADRO & $-0,0128$ & 0,0132 & 0,1148 & 1,5596 & $-0,0122$ \\
2 & AKRA & $-0,0245$ & 0,0101 & 0,1005 & 1,5344 & $-0,0238$
\end{tabular}

$\begin{array}{ccccccc}2 & \text { AKRA } & -0,0245 & 0,0101 & 0,1005 & 1,5344 & -0,0238 \\ 3 & \text { ANTM } & 0,0014 & 0,0200 & 0,1414 & 1,4876 & 0,0020\end{array}$

$\begin{array}{lcccccc}4 & \text { ASII } & -0,0076 & 0,0032 & 0,0568 & 0,9983 & -0,0072\end{array}$

$\begin{array}{lllllll}5 & \text { BBCA } & 0,0183 & 0,0017 & 0,0408 & 0,8250 & 0,0187\end{array}$

$\begin{array}{lllllll}6 & \text { BBNI } & -0,0011 & 0,0068 & 0,0827 & 1,7743 & -0,0004\end{array}$

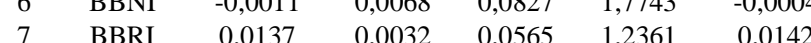

$\begin{array}{ccccccc}7 & \text { BBRI } & 0,0137 & 0,0032 & 0,0565 & 1,2361 & 0,0142 \\ 8 & \text { BBTN } & -0,0110 & 0,0135 & 0,1163 & 1,5137 & -0,0104\end{array}$

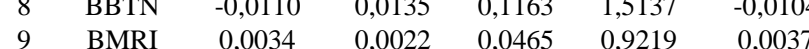

$\begin{array}{ccccccc}9 & \text { BMRI } & 0,0034 & 0,0022 & 0,0465 & 0,9219 & 0,0037 \\ 10 & \text { BRPT } & 0,0455 & 0,0152 & 0,1234 & 0,6641 & 0,0458\end{array}$

11 BSDE $\quad-0,0158 \quad 0,0061 \quad 0,0778 \quad 1,0043 \quad-0,0154$

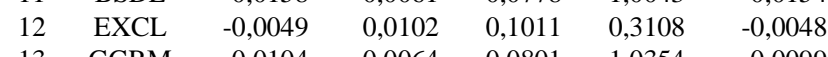

13 GGRM $-0,0104 \quad 0,0064 \quad 0,0801 \quad 1,0354 \quad-0,0099$

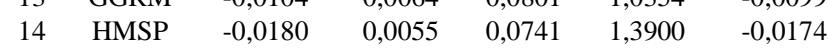

$\begin{array}{lllllll}15 & \text { ICBP } & 0,0103 & 0,0021 & 0,0462 & 0,2887 & 0,0104\end{array}$

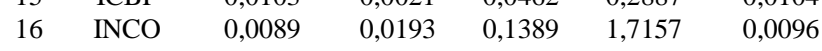

$17 \quad$ INDF $\quad-0,0023 \quad 0,0036 \quad 0,0596 \quad 0,5792 \quad-0,0020$

$18 \quad$ INTP $\quad-0,0020 \quad 0,0153 \quad 0,1239 \quad 2,0189 \quad-0,0012$

19 JSMR $\quad-0,0080 \quad 0,0060 \quad 0,0772 \quad 1,1477 \quad-0,0075$

20 KLBF $\quad-0,0064 \quad 0,0038 \quad 0,0619 \quad 0,9862 \quad-0,0060$

$\begin{array}{lllllll}21 & \text { LPPF } & -0,0487 & 0,0244 & 0,1562 & 1,3309 & -0,0482\end{array}$

$\begin{array}{lllllll}22 & \text { MNCN } & -0,0041 & 0,0216 & 0,1469 & 0,9747 & -0,0037\end{array}$

23 PGAS $\quad-0,0092 \quad 0,0202 \quad 0,1420 \quad 1,6745 \quad-0,0085$

$24 \quad$ PTBA $\quad-0,0057 \quad 0,1795 \quad 0,4237 \quad-2,2995 \quad-0,0066$

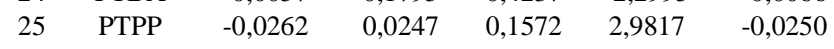

$\begin{array}{lllllll}26 & \text { SCMA } & -0,0165 & 0,0093 & 0,0965 & 1,5880 & -0,0158\end{array}$

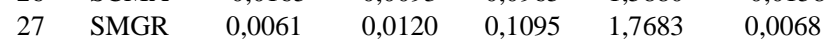

28 SRIL $\quad-0,0143 \quad 0,0036 \quad 0,0600 \quad 0,3333 \quad-0,0142$

29 TLKM $\quad-0,0070 \quad 0,0032 \quad 0,0565 \quad 0,1763 \quad-0,0069$

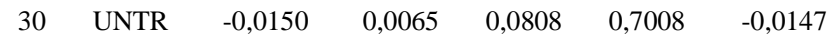

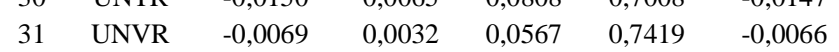

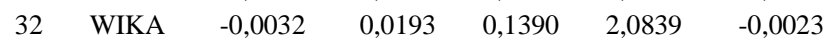

33 WSKT $\quad-0,0221 \quad 0,0179 \quad 0,1339 \quad 2,5334 \quad-0,0211$

$\begin{array}{llll}\text { LQ45 } & -0,0004 & 0,0014 & 0,0373\end{array}$

After all the parameters have been calculated and collected, the next step in forming the optimal portfolio is to calculate the Excess Return to Beta (ERB) of each individual stock, calculate $\mathrm{C}_{-} \mathrm{i}$ which has a positive ERB value, determine the Cut off Point $\left(C^{*}\right)$, which is the $\mathrm{C}_{-} \mathrm{i}$ value where The last ERB value in the list order was still greater than the value of $\mathrm{C}_{-} \mathrm{i}$, and formed an optimal portfolio consisting of individual stocks with $E R B \geq C^{*}$.

Knowing the proportion of these funds will make it easier for investors to allocate their investment funds from all the funds they have to make investments. This proportion of funds can also be used as a guideline for which shares are priority. Calculation of weight $(\mathrm{Zi})$ and weight percentage (Wi) for the four selected LQ-45 stocks.

TABLE II: OPTIMAL PORTFOLIO PROPORTION LQ-45 INDEX SINGLE INDEX

\begin{tabular}{clrr}
\multicolumn{3}{c}{ MODEL (SIM) METHOD } \\
\hline No & \multicolumn{1}{c}{ Company } & $\mathrm{Zi}$ & \multicolumn{1}{c}{$\mathrm{Wi}$} \\
\hline 1 & Barito Pacific Tbk & 2,3768 & $26,80 \%$ \\
2 & Indofood CBP Sukses Makmur Tbk. & 1,7886 & $20,17 \%$ \\
3 & Bank Central Asia Tbk. & 4,6750 & $52,72 \%$ \\
4 & Bank Rakyat Indonesia (Persero) Tbk. & 0,0278 & $0,31 \%$ \\
& & $100,00 \%$ \\
\hline
\end{tabular}

The CAPM method itself is used to calculate the expected rate of return using the risk-free purchase rate variable (Rf), the average market rate of return $[\mathrm{E}(\mathrm{Rm})]$, and also the systematic risk of each stock.

In accordance with the efficient portfolio theory, an efficient portfolio is a portfolio that provides certain returns for investors with minimal risk or offers the same risk conditions with a maximum rate of return.

TABLE III: OPTIMAL PORTFOLIO PROPORTION FOR LQ45 INDEX CAPITAL ASSET PRICING MODEL (CAPM) METHOD

\begin{tabular}{ccc}
\multicolumn{3}{c}{ CAPITAL ASSET PRICING MODEL (CAPM) METHOD } \\
\hline No & Nama & Wi \\
\hline 1 & Barito Pacific Tbk & $4,28 \%$ \\
2 & Bank Central Asia Tbk. & $38,04 \%$ \\
3 & Indofood CBP Sukses Makmur Tbk. & $31,37 \%$ \\
4 & Bank Mandiri (Persero) Tbk. & $26,32 \%$ \\
& & $100,00 \%$ \\
\hline
\end{tabular}

Portfolio performance measurement for the three different methods requires data in the form of portfolio returns, standard deviations, market returns and risk free rates. The results of calculating the portfolio performance of the Single Index Model (SIM) and the Capital Asset Pricing Model (CAPM) can be seen in the following table.

TABLE IV: Portfolio Performance CAlculation Results Single INDEX Model CAPITAL Asset PRICING MODEL

\begin{tabular}{ccc}
\multicolumn{2}{c}{ INDEX MODEL CAPITAL ASSET PRICING MODEL } \\
\hline \multirow{2}{*}{ Single Index Model } & Capital Asset Pricing \\
& Model \\
\hline Sharpe & $41,21 \%$ & $27,95 \%$ \\
Treynor & $2,91 \%$ & $1,28 \%$ \\
Jensen & $2,29 \%$ & $1,12 \%$ \\
\hline
\end{tabular}

The optimal portfolio formed using the Single Index Model has a better performance value when compared to the optimal portfolio formed using the Capital Asset Pricing Model.

\section{A. Research Hypothesis Testing}

One way to find out whether there is a difference in returns or not, it is necessary to test the hypothesis by comparing the portfolio returns of the Single Index Model and the Portfolio of the Capital Asset Pricing Model so that we can find out whether there is a significant difference between the two portfolio returns.

TABLE V: DifFERENT TEST RESUlts PAIRED SAMPLE T-TEST

\begin{tabular}{cccccccc}
\hline & \multicolumn{3}{c}{ Paired Differences } & & & $\begin{array}{c}\text { Sig. } \\
\text { (2-tailed) }\end{array}$ \\
\cline { 2 - 4 } & Mean & $\begin{array}{c}\text { Std. } \\
\text { Dev }\end{array}$ & $\begin{array}{c}\text { Std. Error } \\
\text { Mean }\end{array}$ & t & df & & 0,002 \\
\hline SIM CAPM & 0,017 & 0,028 & 0,005 & 3,36 & 29 & 0
\end{tabular}

These results indicate that there are differences in Single Index Model portfolio returns to the Capital Asset Pricing Model Portfolio returns. This result is in line with previous research [10].

To find out whether there is a difference in risk or not, it is necessary to test the hypothesis by comparing the risk of the Single Index Model portfolio and the Capital Asset Pricing Model portfolio so that we can find out whether there is a significant difference between the two portfolio risks. 
TABLE VI: MANN-WHITNEY U DIFFERENCE TEST RESULTS MANN-WHITNEY TEST

\begin{tabular}{cc}
\multicolumn{2}{c}{ MANN-WHiTNEY TEST } \\
\hline \multicolumn{2}{c}{ Mann-Whitney Test $^{\text {Test Statistics }^{\mathrm{a}}}$} \\
\hline & Risiko \\
\hline Mann-Whitney U & 248,000 \\
Wilcoxon W & 812,000 \\
$\mathrm{Z}$ & $-1,523$ \\
Asymp. Sig. (2-tailed) &, 128 \\
\hline
\end{tabular}

a. Grouping Variable: Portfolio.

These results indicate that there is no difference in the risk of the Single Index Model portfolio to the risk of the Capital Asset Pricing Model Portfolio. This result is in line with previous research [11].

To find out whether there is a difference in performance or not, it is necessary to test the hypothesis by comparing the performance of the Single Index Model portfolio so that we can find out whether there is a significant difference in the performance of the portfolio.

TABLE VII: PORTFOLIO PERFORMANCE DIFFERENT TEST RESULTS

\begin{tabular}{cccccc}
\hline \multicolumn{7}{c}{ ANOVA } \\
\hline \multicolumn{7}{c}{ Nilai } \\
\hline $\begin{array}{c}\text { Sum of } \\
\text { Squares }\end{array}$ & df & $\begin{array}{c}\text { Mean } \\
\text { Square }\end{array}$ & F & Sig. \\
\hline Between Groups & 83,93 & 2 & 41,97 & 8,31 &, 000 \\
Within Groups & 439,22 & 87 & 5,05 & & \\
Total & 523,16 & 89 & & & \\
\hline
\end{tabular}

These results indicate that there are differences in the performance of the Single Index Model portfolio which is evaluated using the Sharpe, Treynor, and Jensen methods. This result is in line with previous research [12].

To find out whether there is a difference in performance or not, it is necessary to test the hypothesis by comparing the performance of the Capital Asset Pricing Model portfolio so that we can find out whether there is a significant difference in the performance of the portfolio.

\begin{tabular}{cccccc} 
TABLE VIII: DIFFERENT TEST RESULTS ON PORTFOLIO PERFORMANCE \\
\hline \multicolumn{7}{c}{ ANOVA } \\
\hline $\begin{array}{c}\text { Nilai } \\
\text { Squares }\end{array}$ & df & $\begin{array}{c}\text { Mean } \\
\text { Square }\end{array}$ & F & Sig. \\
\hline Between Groups & 3,03 & 2 & 1,52 &, 594 &, 555 \\
Within Groups & 222,37 & 87 & 2,56 & & \\
Total & 225,40 & 89 & & & \\
\hline
\end{tabular}

These results indicate that there is no difference in the performance of the Capital Asset Pricing Model portfolio which is evaluated using the Sharpe, Treynor, and Jensen methods. This result is in line with previous research [13].

\section{CONCLUSION}

Based on the results of the research that has been done, (1) There are differences in the return of the Single Index Model portfolio to the return on the Capital Asset Pricing Model Portfolio (2) there is no difference between Single Index Model portfolio risk and Capital Asset Pricing Model portfolio risk, (3) there are differences in the performance of the Single Index Model portfolio which is evaluated using the Sharpe, Treynor, and Jensen methods, and (4) there is no difference in the performance of the Capital Asset Pricing
Model portfolio which is evaluated using the Sharpe, Treynor, and Jensen methods. Suggestions for investors with risk averse preferences (not liking risk) can choose stocks that are included in the optimal portfolio in this study. Because it generates less risk than the risk generated from individual stocks. As for other research, it is recommended to use or compare with other models in forming an optimal portfolio as a stock investment decision making so that it can provide more varied results.

\section{REFERENCES}

[1] Mary, J. F., \& Rathika, G. (2015). The Single Index Model and the Construction of Optimal Portfolio with CNX Pharma Scrip. International Journal of Management (IJM), 6(1), 87-96.

[2] Sharpe, W. (1996). Mutual Fund Performance. Journal of Business, 39.

[3] Jensen, M. (1968). The Performance of Mutual Funds in the Period 1945-1964. Journal of Finance, 23, 89-416.

[4] Jogiyanto. (2010). Teori Portofolio dan Analisis Investasi. BPFE.

[5] Bawazier, Said \& Jati P. Sitanggang (1994). Memilih Saham Untuk Portofolio Optimal. Usahawan, XXIII (1), 34-40.

[6] Edwin, E., \& J, M. (1995). Modern Portfolio Theory and Investment Analysis (Fifth Edit). John Wiley \& Sons, Inc.

[7] Fahmi, Irham. (2015). Pengantar Teori Portofolio dan Analisis Investasi. Bandung: ALFABETA.

[8] Charles Jones (2010). Investments: Principles and Concept. John Willey \& Sons.

[9] Treynor, J. (1996). How to Rate Management Investment Funds. Harvard Business Review, 43.

[10] Maulana, N., I. (2019). Studi Komparatif Keakuratan dengan Menggunakan Metode Capital Asset Pricing Model (CAPM) dan Single Index Model (SIM) pada Indeks IDX30.Skripsi Manajemen Fakultas Ekonomi dan Bisnis. Universitas Pancasakti Tegal.

[11] Amalia, N. (2018). Pembentukan Portofolio Saham Optimal Dengan Menggunakan Model Sim (Single Indeks Model), Dan Capm (Capital Asset Pricing Model). Universitas Muhammadiyah Surakarta.

[12] Tuerah, Citrayani. (2013). Perbandingan Kinerja Saham LQ 45 Tahun 2012 Menggunakan Metode Jensen, Sharpe dan Treynor. Jurnal EMBA, ISSN: 2303-1174, Vol. 1 No. 4, 1444 - 1457.

[13] Nurlaeli, S., \& Artati, D. (2020). Analisis Kinerja Portofolio Saham dengan Metode Sharpe, Treynor, dan Jensen. Jurnal Ilmiah Mahasiswa Manajemen, Bisnis Dan Akuntansi (JIMMBA), 2(6), 972990. https://doi.org/10.32639/jimmba.v2i6.690. 